\title{
Improvement of open field development technology as a factor in the formation of quality and market value of reclaimed land
}

\author{
Yurii Litvinov ${ }^{1 *}$, Yevhen Terekhov ${ }^{1}$, and Volodymyr Fenenko ${ }^{2}$ \\ ${ }^{1}$ Dnipro University of Technology, Department of Applied Economics, Entrepreneurship and Public \\ Administration, 19 Yavornytskoho Ave., 49005 Dnipro, Ukraine \\ ${ }^{2}$ Prydniprovska State Academy of Civil Engineering and Architecture, Department of Roads, \\ Geodesy and Land Organization, 24a Chernyshevskoho St., 49600 Dnipro, Ukraine
}

\begin{abstract}
An analysis of the results of the reproduction of land in an open development of a horizontal mineral deposit has been carried out. The interconnection of the method and the system of open development of the deposit with the qualitative and quantitative levels of land reclamation, as well as their monetary estimation according to the direction of use, is substantiated. The principle of this approach to the planning of land abandonment measures at a mining enterprise from the point of view of the subordination of the technological processes of mining of minerals to the results of the reproduction of land in previous periods is proposed, which allows to take into account the quality of reproduction of land for determining the extent of their violation. The technological scheme of organization of mining works and land reclamation works is shown, which involves synchronization of these processes in terms of disturbance and reproduction of lands, as well as formation of a more qualitative soil layer due to its selective displacement. The components and peculiarities of the formation of the economic effect are determined from the introduction of dynamic schemes for the development of a quarry field on their relation to the cost of land leakage in the development of horizontal mineral deposits in the stages of the life cycle of a quarry.
\end{abstract}

\section{Introduction}

The present-day mining industry is caused by significant violations of natural resources. This is especially true for the open development of deposits, which is becoming increasingly large, in accordance with the needs of mineral resources. Extraction of minerals from the subsoil in an open way leads to a significant change in the environment, which is determined by violations of the surface over the worked areas of deposits and the formation of mining operations in the area of waste heaps and waste processing of minerals. Violating the environment - the earth's surface and the rocky array, the quarries, to a great extent, reduce the quality of the used land resources and change the landscape. This is due

\footnotetext{
${ }^{*}$ Corresponding author: litvinovyuriy82@gmail.com
} 
to the poor adaptation of existing mining schemes, primarily due to the weak interconnection between the method of disclosure and the development system and, as a consequence, the reclamation. A major direction in reducing the volume of land plots from agricultural use without damage to the development of the country's mining industry is the reclamation of disturbed lands. Therefore, the Land Code of Ukraine [1] provides for the mandatory reclamation of land by all users of depths.

Today, taking into account the strengthening of the requirements for the preservation of the natural environment of mining, the emergence of private landowners, the efficiency of the mining cycle can not be considered separately for measures to reproduce miningaffected land development. The layout of the preliminary stages of the development of the deposit must be in line with the objectives of reproduction of the disturbed environment at the final stage of the technological cycle. This makes relevant studies related to the assessment of the impact of technological and organizational factors on the choice of system, the method of capturing the deposit on the quality and the monetary valuation of land to be reclaimed after extractive works in an open way.

In the course of the research, the task was to establish the dependence of the quality of work on land reclamation in relation to the parameters of the system and the method of developing a horizontal mineral deposit. This will allow to create the best technical and organizational conditions for the quick and cost-effective recovery of land affected by open-cast mining.

At the present stage, the technology of mining technical remediation has been studied in sufficient detail, and the complex scientific and practical problem is the level of fertility of the reclaimed land plots $[2,3]$. To date, academic circles have given enough attention to the resolution of issues of technological limitation of violations of natural resources and their maximum restoration on open development. For example, the researchers of the IPPE of the National Academy of Sciences of Ukraine developed and implemented technologies for the restoration of earth-damaged mining works, namely, the Ingulets Ecological Corridor was established [4, 5]. Equally important is the innovative solutions for the introduction of alternative technologies in industrial Prydniprovi, subject to resource constraints [6]. From scientific work [7] it follows that under the influence of an anthropogenic factor negative changes in the environment occur more than their recovery. The authors emphasize the transition to the ecological principles of rational use of land resources, in order to avoid global negative changes in the geosphere. From studies $[8,9]$ it also follows that the renewal of the ecological and aesthetic state of landscapes has an important scientific and applied value for the quality of recultivated lands, their area and the period of return to agriculture.

Polish researchers cited some cases of rehabilitation and restoration of land that "returns", while simultaneously moving the front of mining operations [10]. The importance of recultivation works is reflected in the work [11]. It is emphasized on the possibility of minimizing the level of damage to land resources due to efficient ways of handling the upper layer of soil, namely, favorable conditions for storage of the upper layer of soil, its return to the restoring surface and seeding of the thick vegetation cover. There are many examples of rehabilitation of technogenic landscapes in Germany due to technological approaches to environmental and economic planning.

Scientists [12] analyzed the characteristics of the landscape and land use after the exploitation of minerals in Finland. It is determined that there is a need to pay more attention to technogenic landscapes after extraction of minerals in order to avoid environmental, social and economic consequences. Increasingly in scientific sources attention is paid to the ecological consequences of the development of minerals in an open way, problems of an economic nature, which are caused by the destructive impact of mining enterprises on the environment $[13,14]$. 
In the works $[15,16]$ Sobko B.Yu. proposes a rational way of disclosing of spreading deposit with the formation of a temporary semitrailer, which influences the limitation of natural resources violations, and explores the question of substantiation of the possibilities of reducing the costs of overturning works under open mining conditions. In [17], we consider the relationship between the method of disclosure and the development system in condition that the land is extracted for the development of the deposit and recovery at the boundaries of the quarry field.

In studies Bobrov S.A. [18] attention is focused on the main reasons for the lack of speed and timeliness of reclamation work, which leads to high costs for their implementation in the open development of a powerful generation of their coal seams.

There are also proposals to reduce the distance of transportation by separating the quarry field into two blocks, in which the removal, transportation and storage of overburden in the inner tank are performed variably, rational leveling of dumps "top to bottom" and "bottom-up". In addition, deserves attention to diversification of means of mechanization and improvement of the general organization of works on reclamation of all sites occupied by the objects of the ore dressing mill [19].

The methodological basis for studying the problems of rational nature management, the multifunctionality of technogenic landscapes and the ecological and economic evaluation of the processes of reproduction of land in conditions of open mining of horizontal deposits of minerals is laid down in the works [20 - 22]. Based on the justification of appropriate technologies for the reproduction of land resources, an analysis of the cost effectiveness associated with the formation of land at a certain level of quality and area [23, 24] should be conducted. The economic benefits of faster land reproduction will be the main motivating factor to increase land cover in conditions of horizontal mineral deposits.

A significant drawback of the existing practice of mining technical remediation is the lack of motivation for technological solutions for the restoration of used land to improve their quality, and hence their value, which generally determines the economic efficiency of remediation works. Therefore, today it is important to develop technological and organizational solutions for increasing the efficiency of land reclamation work, by improving the quality of technogenic soil due to its proper storage and timely reproduction, reducing the cost of its formation, creating opportunities for recultivation of a larger area of the mining waste (in particular, the area of the outgoing trenches) due to the construction of temporary congresses, which will be subject to frosting as the front of the mining operations.

\section{Presentation of the main research material}

Typical technological schemes for the development of such deposits, for example, for manganese ore extraction, involve the reclamation of land affected during the construction and exploitation periods. These works are related with the formation of the capital (sloping), outgoing (horizontal) and truncated trenches, which, in the future, will make up the remaining spent space of the quarry, with a considerable area on the surface. Therefore, the volume of mining technical remediation in quarries will be determined not only by the size of outgoing and cut trenches, but also by the scheme for the development of the deposit.

Often, the effectiveness of the development is established from the branch positions. For example, under the rational direction of deepening of the quarry is understood such a direction, which provides the minimum value of the average since the beginning of working out the coefficient of overturning. Use as the main criterion of the coefficient of overturning does not always allow us to estimate the use of the produced space for internal dump formation, on which the volume of the area of the affected lands depends [25]. According 
to the authors, it is the level of qualitative and quantitative reproduction of disturbed lands to be a more informative indicator of the effectiveness of management of the developed quarry area after the completion of mining works.

The scope and effectiveness of spending on land will spark novleling quality remediation, under which is the sum of the properties and usefulness of anthropogenic soils that cause their ability to meet the requirements of next land, particularly agricultural land. Below, in order to assess the quality of remediation (in terms of the quality of restored lands) in open mining, the characteristics of soils, which are common in the lands devoted to the development of a deposit of manganese quarries at Pokrovskyi ore Mining and Processing Plant (Pokrovskyi MPP), have been investigated.

Annually, at the Pokrovskyi MPP quarries, up to 200 million tons of rock mass are being developed and moved. The existing manganese ore extraction technology at the Pokrovskyi MPP involves the use of a large number of mining equipment, high costs for the construction of capital objects and constructions, and significant maintenance and maintenance costs for technological machines, devices and aggregates.

Currently, the enterprise annually removes about 100 hectares of land for the development of the field. These lands are distributed as follows: arable land $-90 \%$, pasture $-4 \%$, farm $-6 \%$. During the time of work, only 10392 hectares of land were occupied by the facilities of the Pokrovskyi MPP, including the largest part of land plots 5849.8 hectares $(56.1 \%$ of the total land area of the Pokrovskyi MPP), where 1721.5 hectares were used under technological trenches, and 4128.3 ha - for the formation of dumps. Under industrial land, $3168(30.4 \%)$ were provided, with 59.07 hectares $(0.6 \%)$ of black earth deposits, 97.9 hectares $(0.9 \%)$ of industrial platforms and carcasses, and 1804 reservoirs ha $(17.3 \%)$, transport and linear communications -580.8 ha $(5.6 \%)$, the rest 543.4 hectares $(5.2 \%)$. Such a structure of land indicates a large technological burden on black earth soils due to large areas allocated for industrial production, and insufficient attention to the preservation and restoration of the quality of fertile land resources.

At an enterprise with 7480 hectares of disturbed land, $63.7 \%$ of the agricultural land was reclaimed. The technology of mining-technical reclamation existing in the quarries leads to the creation of low-fertility soils. The applied black earth layer is more often a mixture of humus and transient horizons of black earth, which causes low and uneven humus content in the areas in the range from 1.8 to $2.2 \%$ (with content in unbroken soils $3.5-4.2 \%$ ). About a third of the total area of the reclaimed areas has either very insufficient $(35 \mathrm{~cm})$, or too powerful $(96 \mathrm{~cm})$ layer of black soil (Table 1).

All reclamation work is carried out by the open-pit equipment of the quarries, which ensures minimal expenses for its carrying out. Until now, the plant has been carrying out reclamation works as recreational (Oleksandrivskyi and Bohdanovskyi Landscape Park), as well as for agricultural areas [26]. If the indicated equipment is well suited for reclamation of used land in a recreational area, then for the creation of agricultural land it is not suitable.

The payback periods for reclamation work are considered to be large (up to $10-15$ years), since in determining their effectiveness, only the self-sustaining effect is taken into account. But this effect in the structure of the overall effect of environmental protection and natural resources is only $20 \%$, and the remaining $80 \%$ is a distorted ecological, economic and social damage. According to a comprehensive assessment of the efficiency of reclamation, the payback period will be reduced to $2.5-3.5$ years.

When an enterprise returns land with less suitability for use in agriculture, it reduces the cost of repairs, but increases the amount of cash compensation. According to the quality of the reclamation work in the quarries considered, the monetary value of 1 hectare of arable land varies from 13.98 to 20.68 thousand UAH. In general, with increasing soil fertility by one or another indicator, their value increases. If the level of all indicators was steadily rising, the cost of recovered soils would be significantly higher. But in fact the dynamics of 
any - of which the fertility rate often does not match the dynamics of other indicators of fertility. It follows that the formation of a certain indicator of soil quality must be consistent with the direction of its use. Excessive fluctuations in the values of these indicators, as a rule, do not lead to a proportional change in the fertility of the land. Thus, land reclamation projects should include such technological solutions that allow uniform formation of soil quality indicators at the level most favorable for its involvement in certain economic uses.

Table 1. Characteristics of the quality of recultivated lands at the quarries of Pokrovskyi MPP.

\begin{tabular}{|l|c|c|c|c|c|}
\hline \multirow{2}{*}{$\begin{array}{c}\text { Quality score } \\
\text { reclaimed land }\end{array}$} & Zaporizkyi & Oleksandrivskyi & Shevchenkivskyi & \multicolumn{2}{|c|}{ Chkalovskyi 1 } \\
\cline { 5 - 6 } & & & & plot 1 & plot 2 \\
\hline $\begin{array}{l}\text { Depth of bulk black earth } \\
\text { layer, cm }\end{array}$ & 55 & 67 & 66 & 68 & 96 \\
\hline Humus content in soil, \% & 2.2 & 1.9 & 1.8 & 2.1 & 1.5 \\
\hline $\begin{array}{l}\text { The content of physical } \\
\text { clay in the layer } \\
0 \text { to 100 cm, \% }\end{array}$ & 51.3 & 41.8 & 51.7 & 53.6 & 50.4 \\
\hline $\begin{array}{l}\text { Economic evaluation } \\
\text { point by performance }\end{array}$ & 22 & 27 & 22 & 20 & 22 \\
\hline $\begin{array}{l}\text { Economic evaluation } \\
\text { point cost recovery }\end{array}$ & 71 & 89 & 73 & 56 & 62 \\
\hline $\begin{array}{l}\text { Estimation on the } \\
\text { differential income of } \\
\text { grain crops, UAH/ha }\end{array}$ & 1632.2 & 1994.9 & 1632.2 & 1223.1 & 1359.1 \\
\hline $\begin{array}{l}\text { Monetary valuation of } \\
1 \text { hectare of arable land, } \\
\text { UAH }\end{array}$ & 17534.7 & 20688.1 & 17534 & 13983.9 & 15165.8 \\
\hline
\end{tabular}

In the conditions of activity of Ukrainian enterprises for mining of mineral raw materials, the whole set of expenses for reclamation in general is distributed in the following proportions: the mining technical stage $-90 \%$, biological $-10 \%$. A reduction in the costs of rehabilitation of used land is a reduction in the technical, biological, organizational and economic conditions for the implementation of this process, which, in its turn, depends on the previous stages of the disclosure and extraction of minerals. Thus, the effectiveness of land reclamation, aimed at improving the quality of reproduced lands, hould increase due to its implementation in a single technological process with the extraction of minerals.

Reclamation work reduces the quality of recovered land, primarily, due to lack of evaluation of the importance of this work as one of the production processes of open field development. At most mining enterprises engaged in the restoration of land, the implementation of remediation works is planned to be delayed due to the movement of the mining operations, which entails the need for the transfer of large masses of rocks and soil after the cessation of the production activity of the enterprise, and, accordingly, the lack of marketing of commodity products and the formation of income. This reduces the motivation of the mining company to fulfill its obligations to reproduce the land at an appropriate level of quality and in terms of volume of violation. Therefore, from the point of view of rational allocation of expenses for reclamation during the planned period of reproduction of the earth, it is more appropriate to apply those schemes for the development of the deposit, which involve the simultaneous execution of extractive and reclamation works. The process of preparing the rocks to remove ensuring conditions of these production processes, and mine reclamation process ought to make possible to obtain permission to conduct these processes in the future. However, first of all, it is necessary to 
get the right to carry out the processes of extraction and processing of mineral raw materials, and only then to ensure the conditions for their effective implementation. Therefore, the restoration of land must be located in the first place in the chain of production processes, which constitute mining technology.

In this approach, on how much time and quality be implemented remediation work shall depend magnitude and timing advance strip and mining ledges that determines the amount and timing of mineral raw materials will change the working conditions drop equipment and maintenance costs and service, which will affect the cost of extraction of raw materials. That is, a qualitative recultivation of land on the area of its annual violation should be the basis for the continuation of the quarry of open-cast mining and extraction work next year for the year of recultivation, which can be reflected using the following scheme (Fig. 1).

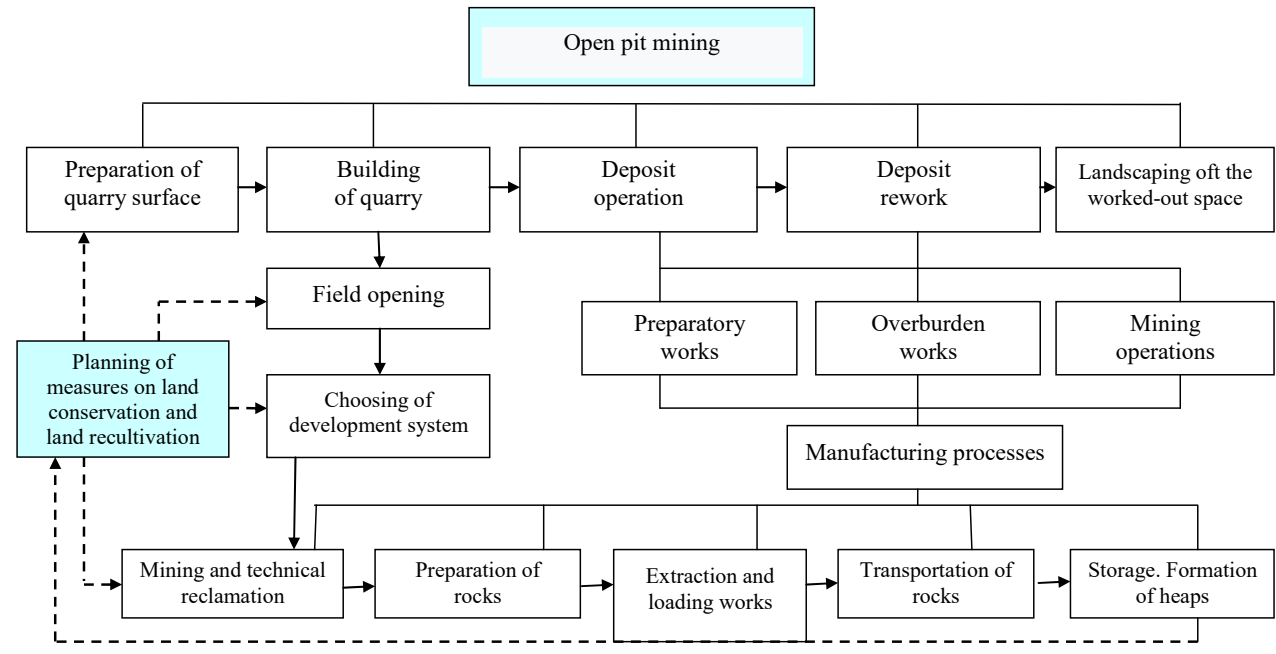

Fig. 1. The sequence of planning the stages of open development of the deposit on the principle of priority land leakage.

Note: ---- schematic elements of the integration of the system of planning the measures for landing in the planning of the technological cycle of mining of mineral raw materials, proposed by the authors.

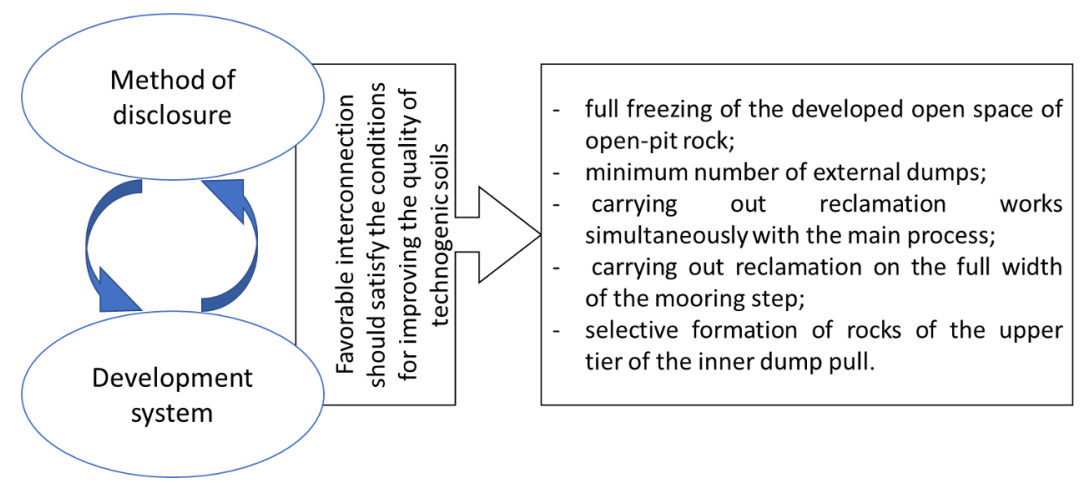

Fig. 2. Influence of favorable interrelation between the way of disclosure of the quarry field and the system of development of the deposit to fulfill the conditions for improving the quality of technogenic soils.

For horizontal deposit method of disclosure and systems of the development is the determining factor limitations in the use of natural resources. There is a close relationship 
between the way of disclosure and the quarry development system (Fig. 2). In general, they must provide each other with favorable conditions for each of their functions: influencing one on one they determine the areas of land needed for the development of the field and can be reclaimed after it for a specific purpose.

The relationship disclosure quarry field method and system should optimize field development so that the produced space quarry became possible completely to fill the overburden and therefore, placing them as small as possible outside contour quarry project, as well conducting the reclamation of land without delay.

\section{Results and discussion}

Usually, in the classical schemes of working out horizontal fields, the length of the front of the excavation works is less than the front of the openings. This is due to the presence of visiting the trench, which serves to transport communications between choices of open-pit bench and surface quarry. Its presence also causes significant difficulties with the placement of overburden. To increase the length of this front, its diagonal placement is proposed [27]. That is, the front of the excavation works is located diagonally to the ends of the quarry, which allows you to increase the length of the front, the productivity of the cantilever dump forming unit, improve the location of the overlying rocks in the dump, and most importantly, with to create favorable conditions for mining technical remediation. The stepping excavator-dragline has a smaller amount of work and cutting of the ditch crest and rough leveling of the surface of the dump in, thus forming an area of considerable size on which the black earth ground can be stored on the progressive ledge, to perform a clean alignment of the waste surface.

However, this approach has a certain disadvantage, namely the presence of an outgoing trench, which occupies large areas of land that are not restored for a long time. To address this shortcoming offered improved flowsheet elements as the synthesized based on the developed by the author of the patent [28], the goal of which is the full use out space by enabling on-site backfill the trench (Fig. 3). This is achieved due to the fact that on the nonworking side and are temporary congresses, which each time during the formation of the next congress, are transferred after the advent of the front of mining operations. Thanks to them is the possibility of more complete filling of the produced space, reduction of the distance of transportation of minerals to the daily surface and preparation of floors for reclamation works.

The proposed technological scheme is implemented as follows. First, in front of the front of the overburden, the scrapers 1 remove the black earth layer with a capacity of $0.55 \mathrm{~m}$ and loam 2 and lay on the roof of the progressive overlapping ledge with drills 3 with a height of $8-10 \mathrm{~m}$. At the same time, the layer of soil is removed in two steps, first top, most fertile, and then lower - potentially fertile. The soils of these two layers are blasted separately, so that soil can be laid in the right order in the future. For the selective removal of soils, special types of equipment are used: scrapers, bulldozers - disintegrators, single-hulled loaders and excavators with small bucket capacity. The development of the deposit is carried out under a combined development system. The advanced opening ledge is worked out by the transport system at the use of the rotary excavator ER-5250, the system of conveyors and dump formers. The breeds are developed selectively: the bottom part of the ledge from shallow soils the dump form moves to the lower part of the bin by the lower spatula (to the surface of the inner bin from the middle ledge), and the upper part of the forward ledge, composed of potentially fertile loams, places it on the freshly poured surface of the bucket. When approaching the barge of black earth 3, which is an intermediate storage for temporary storage of soils, the rotary excavator transmits it to a conveyor belt, located along an advanced ledge. Then the black earth is picked up by a 
rotary excavator and moved by a conveyor to a dump, where the dump form 6 is stored on the planed surface of the dump in separate cones (burts) 5. With subsequent propagation of dumps (after $2-3$ years) the cones of black soil are aligned with special equipment.

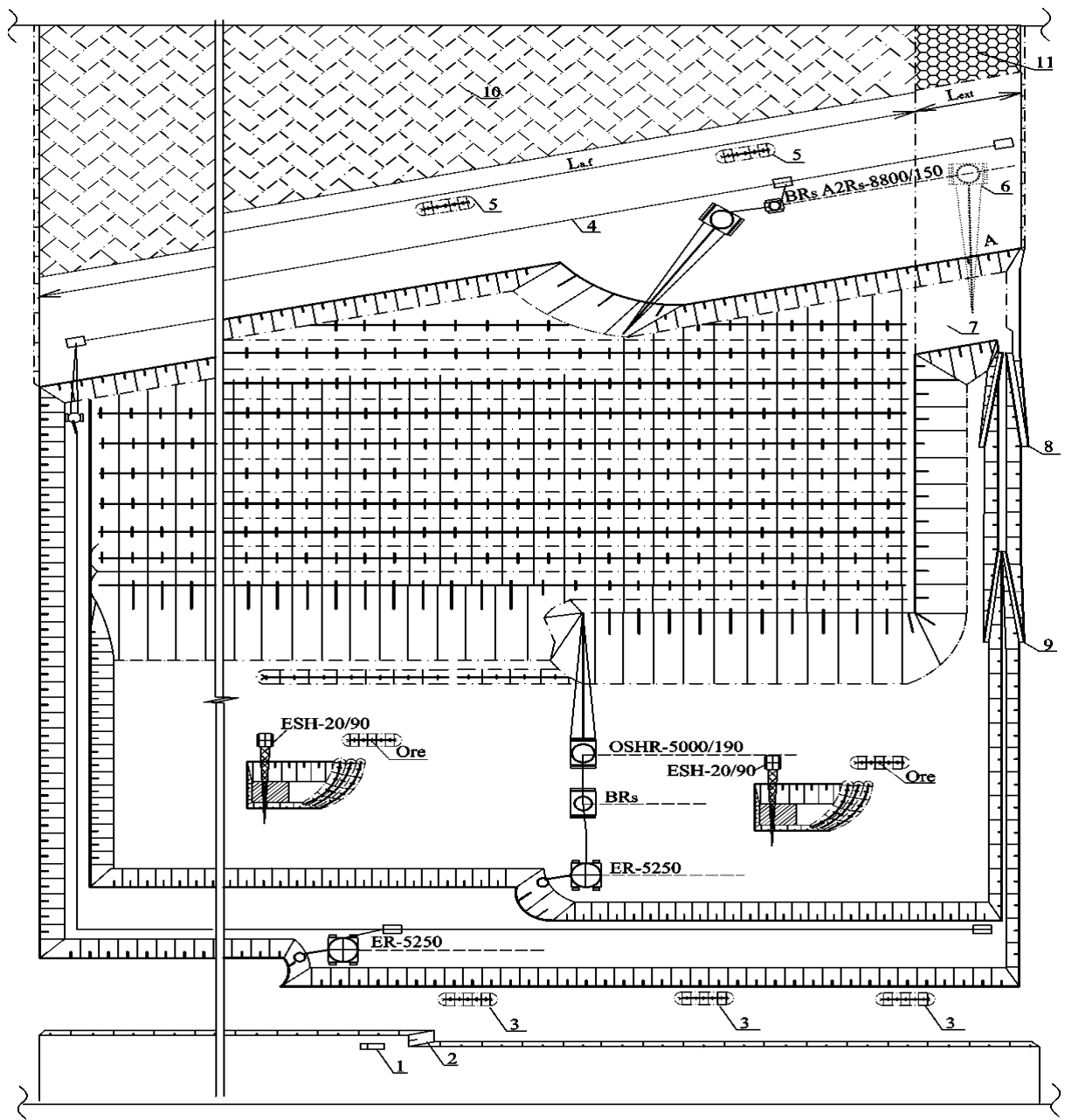

Fig. 3. The proposed technological scheme of horizontal field development.

The main ledge is worked out by the transport-boat scheme with the location of rocks directly in the interior of the boat area of the quarry. Overlapped rocks of the dirty canopy and direct extraction of minerals are worked out by drafts ESH-20/90. The ore is placed in the brothels on the surface of an extraordinary ledge. Then it is shipped to motor vehicles and transported on a created temporary rally 9 to the surface.

As the front of the work on the unplanned quarry side moves along the exit trench, automobile convoys 8 and 9 (Fig. 3), respectively, are formed on the lower and upper ledges with the common connecting platform, which are closer to the working side of the quarry. Since, when filling the exit trench the front of the excavation works in length is larger than the opening front, the conveyor dump can fall into one tier. The front of the excavation works on filling the trench and the rally move ahead with the advance of the front of the upper tier of the excavation works. Next, in the direction of strip advance of the front benches, preparing new car with drive, and with the previous drive to sleep. 
The feature of the proposed scheme is that the length of the drain front can be increased due to more complete use of the produced space 11 , which makes it possible to recultivate the entire surface of the developed open space of the quarry 10. Technological decisions regarding the restoration of land disturbed by open field development and the economic results of mining technical remediation are determined, first of all, by the ratio of the volumes of works in general and the periods of quarry activity. In general, the quantitative assessment of these ratios is carried out on the coefficient of reclamation, which is equal to the ratio of the area of reclaimed land to the area of land affected by mining operations. In connection with the priority of agricultural land use, the level of improvement of the structure of the reclaimed land should be taken into account when assessing the efficiency of the remediation works. Therefore, the impact of mining on the use of land should be evaluated both by the coefficient of reclamation, and by the indicators of fertility of restored lands. That is, it is necessary that the area of restored land-worked quarries increased and the quality increased.

The restoration of work-out quarries of land is closely linked with the development of overlapping ledges: at the speed of moving the front of the work on removing the black earth layer on the surface of the advanced ledge should not delay, and from applying this layer on the surface of the ditch ahead of the front of the openings.

However, promotion of the latter at speed should ensure the advancement of the front of the work on reclamation, sufficient to obtain the required amount of chernozem mass. This volume with the parameters of the area that is being recultivated is bound by the relation:

$$
V_{\text {in.f }} m_{h}\left(L_{a . f}+L_{e x t}+2 B_{s . z}\right)=V_{p . f} m_{n . s h} L_{p . f},
$$

where $V_{i n . f}, V_{p . f}, L_{a . f}, L_{p . f}$ are accordingly the speed of advance and the length of the front of the cavity and overburden; $L_{\text {ext }}$ is extra length front dump operations; $m_{h}, m_{n . s h}$ are average levels according black earth layer of undisturbed land and poured a layer of soil; $B_{s . z}$ is the width of the sanitary protection band.

Analyzing the expression (1), we can conclude that his right side contains indicators that characterize Number natural state land that is given during mining, as well as technological scheme of development. These indicators are the starting point for planning and managing the quality of remediation. The left side of expression (1) reflects the parameters of the reclaimed area, which are adopted by the project, which determine depending on the above source base.

Due to the proposed technological scheme of the development of the deposit in the mode of excavation, there will be no contradiction between the volume of violation of the land and the volume of their reproduction, which makes synchronization of the processes of extraction and reclamation possible. In this case, the cost of land leakage will not undergo significant fluctuations in the annual dimension in accordance with the content of the work of a certain stage of the development of the deposit (Fig. 4).

Effects for the mining company from the introduction of the parameters proposed by the authors of the method and system for the development of mineral deposits from the point of view of the amount of expenses of the mining enterprise for measures related to land-saving will be as follows: 1) reduction of expenses for maintenance of the outgoing trench in working order, provided that it is gradually filled up with overburden $\left.\left(C_{t 1}\right) ; 2\right)$ reducing the costs of moving rocks within the quarry field by reducing the distance of their transportation due to the filling of the exit trench and the simultaneous planning and leveling of the surface for mining technical remediation, without the need to re-move the upper part of the burts during the formation of underlying rocks in the areas of land reclamation $\left.\left(C_{t r 1}\right) ; 3\right)$ reduction of the costs on the recultivation of the ruined surface of the 
earth $\left(C_{r 1}\right)$; 4) reduction of compensatory payments for deterioration of the quality of recultivated lands compared to the state of unaltered lands $\left.\left(C_{k 1}\right) ; 5\right)$ reduction of payments for land lease for mining purposes due to the quick return of land to their owner $\left(C_{\text {rent } 1}\right)$.

The analytical content of these effects (the total economic impact of the mining company $E_{g}$ ) to transfer the system and method of mineral deposits reflects the following expression:

$$
E_{g}=C_{t 1}+C_{t r 1}+C_{r 1}+C_{k 1}+C_{r e n t 1} .
$$

Based on Fig. 4 it can be concluded that the dynamic schemes of the development of the field can reduce the time between violation of the land and their reproduction, and the diagonal placement of the front of the reclamation works will contribute to the harmonization of the rates of violation and reproduction of land in their annual dimension, which, although it will require somewhat higher costs for land abstraction during the extraction stage - recultivation, however, will result in a much lower cost requirement at the stage of completion of the field, since dynamic trenches will gradually fill out the trench completely, unlike in the traditional schemes for the reclamation of which it is necessary to spend substantial amounts of money.

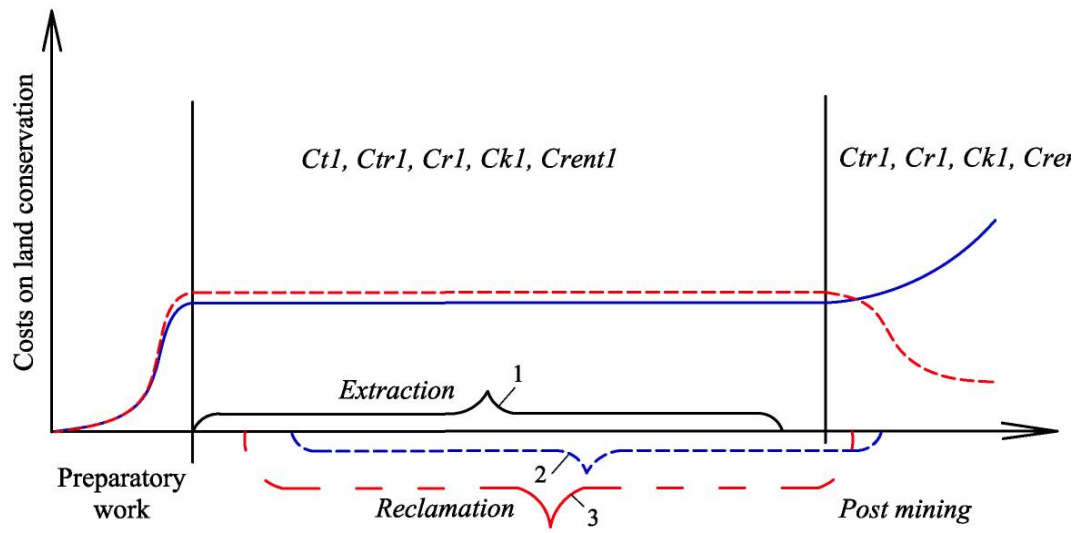

Fig. 4. Graphical interpretation of differences in the cost of land plots by traditional and dynamic technologies of development of the deposit.

Note 1: 1 . The duration of the mining period is $30-40$ years. 2. Duration of land reclamation within the limits of a quarry field on the basis of traditional technology. 3. Duration of land reclamation within the quarry field on the basis of dynamic technology.

Note 2: The components of the effect of land conservation under open mining conditions are depicted by the conditional symbols.

Mining company, proceeding from the position of effective spending of own funds on the conservation of land in conditions of open mining, must strive to ensure that the tempo of increase in the savings of these costs, according to the expression (3), as a result of the implementation of the above technological approaches outpaced or, at least, was equal to the change in the monetary valuation of technogenic lands, the formation of which is possible at a certain level of their quality state and the area on which the reclamation is carried out. In this case, its own effect of saving money will be greater in terms of the unit value of the created land. In the following expression indicators with index " 1 " reflect the technological solutions associated with the implementation of the above technological approaches to land leakage in the open development of the field. Indexes with index " 0 " refer to the previous technical and economic conditions for the development of the field. 


$$
1-\frac{C_{c 1}+C_{c r 1}+C_{r 1}+C_{k 1}+C_{r e n t 1}}{C_{c 0}+C_{c r 0}+C_{r 0}+C_{k 0}+C_{r e n t 0}} \geq 1-\frac{P_{l 1} \cdot S_{l 1}}{P_{l 0} \cdot S_{l 0}},
$$

where $S_{l 1}, S_{l 0}$ are correspondingly the area of the land of the mine, to be reclaimed by the proposed and original technology of the development of the deposit; $P_{l 1}, P_{l 0}$ are respectively, the monetary valuation of land mines to be reclaimed by the proposed and original technology of the development of the deposit.

Based on the practice of Pokrovskyi MPP, the cost of mining technical remediation of land is about $4 \%$ of the technological cost of manganese ore products. As part of these costs, the company does not provide high quality indicators of recultivated land. However, the cost reduction of processes related to mining technical remediation of the above mentioned constituents will allow, without changing the total cost of reclamation, to provide a higher level of quality of restored lands due to more rational spending of funds to reproduce a unit of their area. This, accordingly, will increase the motivation of the mining company in relation to increase the level of reproduction of land not only in terms of area of violations, but also in terms of their quality.

\section{Conclusions}

Based on the practice of reproduction of land under open mining conditions, it has been established that the improvement of technology and the organization of coordinated implementation of the stages of the development of the deposit with the provision of key importance to the processes of land reclamation is an important direction for the development of mining activities on the basis of the rational use of natural resources of mining development. Such technological changes will contribute to the formation of a higher monetary value of recultivated lands, and, accordingly, to increase the efficiency of works on their reproduction.

It is established that the decrease in the loss of open mining development for land resources necessary determination enabling interconnection between the method of disclosure and field development system that will reduce the extent of lands extractive processes and, consequently, their land capacity. Also, minimization of the time lag between the processes of land cultivation and their subsequent restoration will help to minimize the damage from land mines by mining, according to which technological solutions for changing the exposure of the front of rehabilitation works are proposed in order to align it with the length of the front of the extraction works in order to synchronize the processes of cultivation and reclamation lands.

Priority of land abstraction in planning mine work justification of measures to reduce the land use intensity of the production and work on the reclamation of waste land should begin the technological cycle of development of the deposit and determine the appropriate methods and systems of development that will meet the requirements of reproduction and protection of land in terms of violations, reclamation and quality of rehabilitated lands . This will make it possible to create favorable technical and organizational conditions for the early return of land removals of various degrees of violation to economic use and more efficient and economically sound spending on land conservation in the open development of the field.

The formation of technogenic lands of the highest quality and monetary valuation must be achieved by technological and organizational support for the processes of their reproduction, which envisages creation of favorable conditions for reducing the technogenic load on the alienated for the needs of the development of the land by introducing dynamic schemes for the development of the field, avoiding external dump 
formation, selective extraction and movement of soil and rocks, synchronization of the extraction process and works on reclamation on the volume of the involved land.

We express our special gratitude to the scientific leader of the prof. Prokopenko V.I. for professional assistance and support in preparing the article.

\section{References}

1. Zemelnyi kodeks Ukrainy. (2001). Kyiv: Verkhovna Rada Ukrainy.

2. Kononenko, Yu.V. (2002). Raschet parametrov form tekhnogennogo rel'yefa dlya rekjul'tivatsii narushennykh zemel'. Gornyy Informatsionno-Analiticheckiy Byulleten', (12), 135-137.

3. Skvortsov, V.A. (2003). Rekul'tivatsiya zemel' kak faktor ikh ratsional'nogo ispol'zovaniya i ozdorovleniya okruzhayushchey prirodnoy sredy. Zbirnyk Naukovykh Prats Natsionalnoho Hirnychoho Universytetu, 2(17), 611-615.

4. Bulakhov, V.L., Shapar', A.G., Romanenko, V.N., \& Postolovskiy, V.V. (2003). Formirovanie landshaftnogo raznoobraziya pri organizatsii zapovedno-okhranyaemykh territoriy kak ekologicheskaya mera uspeshnoy biologicheskoy reabilitatsii otrabotannykh zemel' gornorudnymi razrabotkami. Ekolohiia i Pryrodokorystuvannia, (5), 126-131.

5. Shapar, A.H., Skrypnyk, O.O., Kopach, P.I., Smetana, S.M., Smetana, O.M., \& Romanenko, V.N. (2007). Naukovo-metodychni rekomendatsii shchodo polipshennia ekolohichnoho stanu zemel, porushenykh hirnychymy robotamy (stvorennia tekhnohennykh landshaftnykh zakaznykiv, ekolohichnykh korydoriv, vidnovlennia ecosystem). Dnipropetrovsk: Monolit.

6. Shapar, A.H., Yemets M.A., Kopach, P.I., Prosandieiev, M.I., \& Skrypnyk O.O. (2014). Osnovni napriamky vprovadzhennia alternatyvnykh tekhnolohii v promyslovomu Prydniprovi za umov resursnoho obmezhennia. Ekolohiia i Pryrodokorystuvannia, (18), 111-121.

7. Nadtochii, P.P., Myslyva, T.M., Morozova, V.V., \& others. (2007). Okhorona ta ratsionalne vykorystannia pryrodnykh resursiv $i$ rekultyvatsiia zemel. Zhytomyr: Derzhavnyi ahroekolohichnyi universytet.

8. Kuter, N. (2013). Reclamation of Degraded Landscapes due to Opencast Mining. Advances in landscape architecture. Croatia. https://doi.org/10.5772/55796

9. Xu, X., Gu, X., Wang, Q., Liu, J., \& Wang, J. (2014). Ultimate pit optimization with ecological cost for open pit metal mines. Transactions of Nonferrous Metals Society of China, 24(5), 15311537. https://doi.org/10.1016/s1003-6326(14)63222-2

10. Kasztelewicz, Z. (2014). Approaches to Post-Mining Land Reclamation in Polish Open-Cast Lignite Mining. Civil And Environmental Engineering Reports, 12(1), 55-67. https://doi.org/10.2478/ceer$\underline{\text { 2014-0006 }}$

11. Wirth, P., Cernic-Mali, B., \& Fischer, W. (2012). Post-Mining Regions in Central Europe Problems, Potentials, Possibilities. Nurnberg: Digital Print Group.

12. Kivinen, S. (2017). Sustainable Post-Mining Land Use: Are Closed Metal Mines Abandoned or Re-Used Space? Sustainability, 9(10), 1705. https://doi.org/10.3390/su9101705

13. Gorova, A., Pavlychenko, A., Borysovs'ka, O., \& Krups'ka, L. (2013). The development of methodology for assessment of environmental risk degree in mining regions. Annual ScientificTechnical Collection - Mining of Mineral Deposits, 207-210. https://doi.org/10.1201/b16354-37

14. Gorova, A., Pavlychenko, A., Kulyna, S., \& Shkremetko, O. (2012). Ecological problems of postindustrial mining areas. Geomechanical Processes During Underground Mining, 35-40. https://doi.org/10.1201/b13157-7

15. Sobko, B.Yu. (2010). Obhruntruvannia ratsionalnykh tekhnolohichnykh skhem rozrobky rozsypnykh rodovyshch Ukrainy. Heotekhnichna Mekhanika, (91), 211-217.

16. Sobko, B.Yu., Lozhnikov, O.V., Haidin, A.M., \& Laznikov, O.M. (2016). Substantiation of rational mining method at the motronivskyi titanium-zirconium ore deposit exploration. Naukovyi Visnyk Natsionalnoho Hirnychoho Universytetu, (6), 41-48. 
17. Gumenik, I.L., Panasenko, A.I., \& Letuchiy, V.V. (2009). Ekologo-ekonomicheskaya otsenka sposobov vskrytiya gorizontal'nykh mestorozhdeniy. Gornyy Informatsionno-Analiticheskiy Byulleten', (11), 335-341.

18. Bobrov, S.A. (2016). Obosnovanie tekhnologii pri otkrytoy razrabotke moshchnykh pologozalegayushchikh ugol'nykh plastov, $\mathrm{PhD}$ Thesis. Krasnoyarsk, Russia.

19. Mosinets, V.N., Shestakov, V.A., Avdeev, O.K., \& Mel'nichenko, V.M. (1981). Okhrana okruzhayushchey sredy pri proektirovanii i ekspluatatsii rudnikov. Moskva: Nedra.

20. Mormul, T.M., \& Terekhov, Ye.V. (2017). Environmental and economic estimation of technological solutions in terms of land resource conservation in the process of open-cast mining. Naukovyi Visnyk Natsionalnoho Hirnychoho Universytetu, (3), 122-128.

21. Prokopenko, V.I., \& Litvinov, Yu. I. (2017). Environmental orientable imperative of developing the technology and excavation of horizontal fields. Naukovyy Visnyk Natsionalnoho Hirnychoho Universytetu, (2), 51-57.

22. Terekhov, Ye.V., \& Litvinov, Yu.I. (2018). Eco-oriented management of manufacturing and supply activity of manganese ore raw materials supplier. Naukovyi Visnyk Natsionalnoho Hirnychoho Universytetu, (4), 166-174. https://doi.org/10.29202/nvngu/2018-4/20

23. Shvets, O.H. (2015). Problemy otsinky efektyvnosti vidnovlennia tekhnohenno porushenykh zemel. Naukovyi Visnyk Khersonskoho Derzhavnoho Universytetu, 13(4), 124-127.

24. Halahan, T.I. (2015). Ekoloho-ekonomichna otsinka rekultyvatsii porushenykh zemel stepovoho Prydniprovia. Visnyk Dnipropetrovskoho Derzhavnoho Ahrarno-Ekonomichnoho Universytetu, (1), 139-143.

25. Rysbekov, K., Huayang, D., Kalybekov, T., Sandybekov, M., Idrissov, K., Zhakypbek, Y., Bakhmagambetova, G. (2019). Application features of the surface laser scanning technology when solving the main tasks of surveying support for reclamation. Mining of Mineral Deposits, 13(3), 40-48. https://doi.org/10.33271/mining13.03.040

26. Bulakhov, V.L., Romanenko, V.N., \& Tarasov, V.V. (2000). Orhanizatsiia zapovidnookhoronnykh terytorii u vtorynnykh ekosystemakh - shliakh do vidnovlennia ekolohichno stiikoho rozvytku industrialnykh rehioniv. Ekolohiia i pryrodokorystuvannia, (2). 161-139.

27. Fenenko, V.I. (2006). Tekhnolohichni zasady pidvyshchennia yakosti hirnychotekhnichnoi rekultyvatsii zemel, porushenykh marhantsevymy karieramy. PhD Thesis. Dnipropetrovsk, Ukraine: Natsionalnyi hirnychyi universytet.

28. Prokopenko, V.I., Vesel, M.M., \& Litvinov, Yu.I. (2016). Sposib vidkrytoi rozrobky horyzontalnoho rodovyshcha. Patent No.112027, Ukraine. 